Loyalitas Kreativitas Aldi Masyarakat Kreatif

\title{
MEMUTUS RANTAI PENULARAN COVID-19 DENGAN MENERAPKAN PROTOKOL KESEHATAN 5 M PADA ANAK SEKOLAH DI TAMAN BACAAN PERIGI YANG BERTEPAT DI JALAN PAHLAWAN NO.48 RT.04/RW.07 KEDAUNG, SAWANGAN, DEPOK
}

\author{
Krisna Priyoadi,Widia Astuti, Muhamad Lavif, \\ Muhammad Sopian, ,Pinsa Noor Septa, Dwi Gusmantri . \\ Dosen Dan Mahasiswa Prodi Manajemen Fakultas Ekonomi \\ Universitas Pamulang
}

Email : krisna.priyoadi@gmail.com,dosen01265@unpam.ac.id,muhamadlavif00@gmail.com ,pinsanoorsepta@gmail.com,dwi.gusmantri@gmail.com , Muhammadsopian420@gmail.com

\begin{abstract}
Health education and promotion plays a major role in handling COVID-19. During the pandemic, the government has recommended all citizens to apply $5 M$, namely using masks, washing hands, and maintaining distance. With good health education and promotion, the level of spread of COVID-19 can be reduced. Education is one of the public health efforts to prevent the spread of COVID-19. One of the prevention and control of COVID-19 is by giving vaccines. However, until now the COVID-19 vaccine is still in clinical trials and there is no COVID-19 vaccine that has been approved for administration to patients. Vaccinations in the future are expected to help achieve herd immunity. Health promotion regarding how to prevent COVID-19 is very important to be given to the community. In addition, information about the mode of transmission and the severity of the disease can also be provided to increase public awareness. Information can be provided through social media and printed media, such as posters and pamphlets.
\end{abstract}

Keywords: Educations; Health

\begin{abstract}
ABSTRAK
Edukasi dan promosi kesehatan memegang peran utama dalam penanganan COVID-19. Selama masa pandemi, pemerintah telah merekomendasikan seluruh warga untuk menerapkan $5 \mathrm{M}$, yaitu menggunakan masker, mencuci tangan, dan menjaga jarak. Dengan edukasi dan promosi kesehatan yang baik maka tingkat penyebaran COVID-19 dapat ditekan. Edukasi merupakan salah satu upaya Kesehatan masyarakat untuk mencegah penyebaran COVID-19. Salah satu pencegahan dan pengendalian penyakit COVID-19 adalah dengan pemberian vaksin. Akan tetapi, sampai sekarang vaksin COVID-19 masih dalam uji klinis dan belum terdapat vaksin COVID-19 yang telah disetujui pemberiannya pada pasien. Vaksinasi di masa depan diharapkan dapat membantu mencapai herd immunity. Promosi kesehatan mengenai cara pencegahan COVID-19 sangat penting diberikan kepada masyarakat. Selain itu, pemberian informasi mengenai cara transmisi dan tingkat keparahan penyakit juga dapat diberikan untuk meningkatkan kewaspadaan masyarakat. Pemberian informasi dapat diberikan melalui media sosial dan media cetak, seperti poster dan pamphlet.
\end{abstract}

Kata Kunci: Edukasi; Kesehatan 
Loyalitas Kreativitas Aldi Masyarakat Kreatif

\section{PENDAHULUAN}

Akhir tahun 2019 tepatnya pada bulan desember, dunia dihebohkan dengan sebuah kejadian yangmembuat banyak masyarakat resah yaitu dikenal dengan virus corona (covid-19). Kejadian tersebut bermula di Tiongkok, Wuhan. Pada awalnya virus ini diduga akibat paparan pasar grosir makanan laut huanan yang banyak menjual banyak spesies hewan hidup. Penyakit ini dengan cepat menyebar di dalam negeri ke bagian lain China. Tanggal 18 Desember hingga 29 Desember 2019, terdapat lima pasien yang dirawat dengan Acute Respiratory Distress Syndrome (ARDS). Sejak 31 Desember 2019 hingga 3 Januari 2020 kasus ini meningkat pesat, ditandai dengan dilaporkannya sebanyak 44 kasus.

Munculnya 2019-nCoV telah menarik perhatian global, dan Pada 30 Januari WHO telah menyatakan COVID-19 sebagai darurat kesehatan masyarakat yang menjadi perhatian internasional. Penambahan jumlah kasus COVID-19 berlangsung cukup cepat dan sudah terjadi penyebaran antar negara. Sampai dengan tanggal 25 Maret 2020, dilaporkan total kasus konfirmasi 414.179 dengan 18.440 kematian (CFR 4,4\%) dimana kasus dilaporkan di 192 negara/wilayah. Diantara kasus tersebut, sudah ada beberapa petugas kesehatan yang dilaporkan terinfeksi (Kemenkes RI, 2020).

Coronavirus Disease 2019 (COVID-

19) adalah penyakit jenis baru yang belum pernah diidentifikasi sebelumnya pada manusia. Virus penyebab COVID-19 ini dinamakan Sars-CoV-2. Virus corona adalah zoonosis (ditularkan antara hewan dan manusia). Adapun, hewan yang menjadi sumber penularan COVID-19 ini masih belum diketahui. Berdasarkan bukti ilmiah, COVID-19 dapat menular dari manusia ke manusia melalui percikan batuk/bersin (droplet), Orang yang paling berisiko tertular penyakit ini adalah orang yang kontak erat dengan pasien COVID-19 termasuk yang merawat pasien COVID-19
(Kemenkes RI, 2020). Tanda dan gejala umum infeksi covid-19 termasuk gejala gangguan pernapasan akut seperti demam, batuk, dan sesak napas. Masa inkubasi ratarata adalah 5 - 6 hari dengan masa inkubasi demam, batuk, dan sesak napas. Pada kasus yang parah, covid-19 dapat menyebabkan pneumonia, sindrom pernapasan akut, gagal ginjal, dan bahkan kematian. Indonesia adalah negara berkembang dan terpadat keempat di dunia, dengan demikian diperkirakan akan sangat menderita dan dalam periode waktu yang lebih lama. Ketika coronavirus novel SARSCoV2 melanda Cina paling parah selama bulanbulan Desember 2019 - Februari 2020. Pada 27 Januari 2020, Indonesia mengeluarkan pembatasan perjalanan dari provinsi Hubei, yang pada saat itu merupakan pusat dari COVID-19 global, sementara pada saat yang sama mengevakuasi 238 orang Indonesia dari Wuhan. Presiden Joko Widodo melaporkan pertama kali menemukan dua kasus infeksi COVID-19 di Indonesia pada 2 Maret 2020. Pasien yang terkonfirmasi covid-19 di Indonesia berawal dari suatu acara di Jakarta dimana penderita kontak dengan seseorang warga Negara asing (WNA) asal Jepang yang tinggal di Malaysia. Setelah pertemuan tersebut penderita mengeluh demam, batuk dan sesak nafas (WHO, 2020).

Corona virus 2019 atau COVID-19 merupakan pandemi yang telah mengakibatkan tingginya angka mortalitas di berbagai belahan dunia. Pengetahuan mengenai pandemi COVID-19 yang baik dan perilaku hidup bersih dan sehat sebagai upaya mencegah penularan COVID-19 penting untuk diterapkan. Tujuan penelitian sebelum dilaksanakannya program ini adalah untuk mengetahui gambaran pengetahuan masyarakat tentang pandemi COVID-19 dan perilaku masyarakat di masa pandemi COVID-19.

Wabah penyakit coronavirus (COVID-19) telah dinyatakan darurat kesehatan masyarakat oleh World Health 
Loyalitas Kreativitas Aldi Masyarakat Kreatif
Organization (WHO) dan virusnya kini telah menyebar ke banyak negara dan wilayah. Banyak korban telah meninggal yang disebabkan COVID-19 ditularkan melalui kontak langsung dengan orang yang terinfeksi. Penting bagi warga sekolah untuk mengambil tindakan pencegahan penularan lebih lanjut serta mengurangi dampak wabah dan mendukung program pemerintah menangani Virus Corona. Perlindungan anak-anak dan fasilitas pendidikan sangat penting. Tindakan pencegahan oleh setiap lembaga pendidikan diperlukan untuk mencegah potensi penyebaran COVID-19 di lingkungan sekolah. Dalam persiapan menuju tatanan kenormalan yang baru, maka diperlukan kedisiplinan warga sekolah serta persiapan dan pengaturan kelas yang sehat untuk mencegah penyebaran Virus Corona pada Anak Usia Dini. Selanjutnya untuk memenuhi kebutuhan psikologis siswa berupa kelekatan emosional dan untuk mempertahankan profesionalitas seorang guru dalam menyelengarakan pendidikan dan mencegah penyebaran pandemi Corona maka tetaplah diperlukan kelas fisik disertai Program PAUD Sehat dengan mengutamakan pelaksaan protokol Kesehatan dari pemerintah secara disiplin. Pemerintah Indonesia telah menetapkan langkah-langkah dan upaya pencegahan pandemi covid-19, salah satunya adalah dengan mensosialisasikan gerakan Social Distancing. Himbauan untuk mengenakan masker dan memperhatikan protokol kesehatan saat beraktivitas di luar rumah masih diabaikan. Di situasi dan kondisi saat ini, kesadaran seluruh masyarakat untuk patuh dan taat dalam menjalankan protokol kesehatan memiliki peranan yang signifikan, sehingga perlu ditekankan kepada seluruh masyarakat untuk mematuhi protokol Covid-19 agar mengurangi penyebaran virus pada masyarakat. Tujuan dari pengabdian ini adalah untuk mencegah dan memutus mata rantai penularan Covid-19 pada masyarakat dimulai dari anak-anak. Pengabdian pada Masyarakat yang diselenggarakan pada tanggal 08 April 2021 ini dilaksanakan dalam bentuk sosialisasi mengenai Covid-19 serta bahayanya virus tersebut, kemudian memberikan penjelasan mengenai protocol kesehatan diantaranya cara mencuci tangan dengan baik dan benar, cara memakai masker dan menjelaskan tentang social distancing, dan mengenali ciri-ciri apabila seseorang terkena Covid-19. Adapun metode yang digunakan dalam pelaksanaan pengabdian ini adalah melalui edukasi kepada anak-anak sekolah dasar (MI) dengan menghimbau pentingnya menggunakan masker. Setelah diberikan edukasi, anak-anak mulai sadar mengenai Covid-19 serta bahayanya virus tersebut, kemudian pentingnya mematuhi protokol kesehatan diantaranya cara mencuci tangan dengan baik dan benar, cara memakai masker dan menjelaskan tentang social distancing, dan mengenali ciri-ciri apabila seseorang terkena Covid-19. Penggunaan masker, dan menjalani protocol kesehatan dalam rangka pencegahan covid-19 ini sangat penting karena dengan demikian, anak-anak di sekolah dapat beraktivitas dengan lebih nyaman dan selalu waspada.

\section{Tujuan Penerapan Protokol Kesehatan 5 M}

Tujuan dari penyuluhan ini yaitu untuk membuat masyarakat Taman baca Prigi untuk sadar dan lebih peduli terhadap protokol Kesehatan dilingkungannya agar virus Covid-19 dapat diputus penyebarannya ditempat umum.

\section{Menerapkan Protokol Kesehatan 5 M di Lingkungan Taman Baca Menerapkan Protokol} Kesehatan 5 M di sekolah adalah upaya untuk memutus rantai penyebaran virus Covid-19 dilingkungan Sekolah. Makna gerakan 5M protokol kesehatan adalah sebagai pelengkap aksi 3M. yaitu: 
1. Memakai masker,

2. Mencuci tangan pakai sabun dan air mengalir,

3. Menjaga jarak,

4. Menjauhi kerumunan, serta

5. Membatasi mobilisasi dan interaksi.

\section{Manfaat Penerapan Protokol}

\section{Kesehatan 5 M d}

Manfaat Penerapan protokol

Kesehatan $5 \mathrm{M}$ di lingkungan sekolah yaitu agar memutus rantai penyebaran virus covid-19 dilingkungan Taman baca. Dengan adanya penerapan tersebut maka lingkungan Taman baca akan menjadi lebih bersih dan sehat sehingga lingkungan Taman baca terhindar dari virus Corona-19 dan jika protokol Kesehatan dilaksanakan dilingkungan Taman baca maka tidak ada kekhawatiran bagi pengunjung yang akan datang ke Taman baca.

\section{METODE PELAKSANAAN KEGIATAN}

Metode pendekatan untuk pelaksanaan kegiatan PKM pada masyarakat Taman baca Prigi ini meliputi metode diskusi, dan seminar. Metode diskusi dilaksanakan pada kegiatan seminar Protokol Kesehatan "Edukasi tentang pentingnya mematuhi protokol kesehatan 5 M". Metode yang digunakan pada kegiatan ini adalah menggunakan metode penyuluhan. Melalui kegiatan pelatihan ini diharapkan dapat mencegah penularan virus Covid-19 dilingkungan Taman baca.

\section{HASIL DAN PEMBAHASAN}

Berdasarkan wawancara, tanya jawab dan pengamatan langsung selama kegiatan berlangsung, kegiatan PKM pada Taman baca Perigi ini memberikan hasil sebagai berikut :

1. pelaksana kegiatan berusaha membantu untuk mengedukasi masyarakat di Taman baca Prigi tentang bahaya covid-19 yang dapat mengancam nyawa, sekaligus praktek untukmemenuhi protocol Kesehatan guna mencegah penyebaran virus corona.

2. Pada sosialisasi pada Taman baca Prigi, mengusulkan untuk mengadakan kegiatan seminar protocol kesehatan. Sosialisasi ini dilaksanakan untuk memberikan wawasan dan informasi tambahan bagi para masyarakat Taman baca Prigi.

3. Kegiatan pelatihan ini juga dilakukan praktek cara mematuhi protocol Kesehatan, seperti cara memakai masker, handsanitizer, serta cara cuci tangan yang baik dan benar.

4. Kegiatan selanjutnya adanya kegiatan diskusi dan Tanya jawab dengan peserta sosialisasi yang dikemas melalui Focus Grup Discusion (FGD).

\section{KESIMPULAN DAN SARAN}

\section{a. Kesimpulan}

Berdasarkan hasil kegiatan PKM pada masyarakat Taman baca Prigi dapat disimpulkan hal-hal sebagai berikut:

1. memberikan tambahan wawasan dan pengetahuan murid-murid Taman baca Prigi tentang bahaya virus corona.

2. menumbuhkan kesadaran murid Taman baca Prigi dalam mematuhi protocol Kesehatan untuk mencegah penyebaran virus corona.

3. membantu masyarakat Taman baca Prigi dalam mengidentifikasi ciri ciri seseorang yang terjangkit virus corona. 
Loyalitas Kreativitas Aldi Masyarakat Kreatif
P-ISSN 2722-2101, E-ISSN 2722-4201

Program Studi Ekonomi Manajemen Universitas Pamulang Jurnal LOKABMAS Kreatif Vol.02,No.03.Nov 2021 Hal.1-7 Email:jurnalkreatif.manajemen@gmail.com

\section{b. Saran}

Bagi pengelola Taman baca Prigi dapat ditingkatkan Kembali kesadaran mengenai protokol Kesehatan 5 M, agar dapat memutus penularan virus Covid19 ditempat umum terutama wilayah Taman baca Prigi.

\section{UCAPAN TERIMAKASIH}

Ucapan terimakasih atas terlaksananya kegiatan pengabdian ini disampaikan kepada:

1. Universitas Pamulang.

2. Dekan Fakultas Ekonomi Universitas Pamulang.

3. Kepala Program Studi Manajemen yang telah memberikan persetujuan dan motivasi dalam terlaksananya kegiatan ini.

4. Budhi Prabowo, SE, MM selaku dosen pembimbing dalam program PKM mahasiswa.

5. Ketua dan Pengurus Katang Taruna Pemuda Pancasila Kembangan Selatan.

6. Rekan-rekan mahasiswa Univeristas Pamulang

7. Berbagai pihak yang membantu dalam terlaksananya kegiatan ini.

\section{DAFTAR PUSTAKA}

Pasaribu, V. L. D., Agrasadya, A., Shabrina, N., \& Krisnaldy, K. (2020). Menjadi Enterpreneur Muda Yang Memiliki Jiwa Leadership Untuk Menghadapi Masa Depan. Abdi Laksana: Jurnal Pengabdian Kepada Masyarakat, 1(1).

Pasaribu, V. L. D., Susanti, F., \& Hartuti, E. T. K. (2019). Memotivasi Siswa dan Siswi SMK Letris Indonesia di Dalam Menentukan Pilihan Untuk Melanjutkan Pendidikan Atau Bekerja Setelah Lulus Sekolah. Jurnal Pengabdian
Dharma Laksana, 1(2), 161-172.

Pasaribu, V. L. D., Sulaiman, S., Sutiman, S., Thaharudin, T., \& Purnomo, B. Y. (2020). Pengenalan Letak Posyandu Terdekat Dikelurahan Pisangan Dengan Manajemen Pemasaran Revolusi 4.0 Untuk Meningkatkan Pengetahuan Masyarakat Letak Dan Fungsi Posyandu Terdekat Pada Kelurahan Pisangan. Dedikasi Pkm, 1(1), 105110.

Pasaribu, V. L. D., Oktrima, B., Prabowo, B., Arianto, N., \& Haryoko, U. B. (2020). Progam Pendampingan Dan Penyelenggaraan Pendidikan Anak Pada Usia Dini Terhadap Prestasi Belajar Dilingkungan Rt $020 \mathrm{Rw}$ 009. Kel Giri Peni. Kec Wates. Yogyakarta. Jurnal Lokabmas Kreatif, 1(1), 71-75.

Pasaribu, V. L. D., Jannah, M., Fazar, M., Putra, S. P., Monalisa, M., \& Sofa, M. (2021). MENINGKATKAN PRODUKTIVITAS USAHA DIMASA PANDEMI PADA IBU PKK RT 004/003 KELURAHAN SAWAH BARU CIPUTAT, TANGERANG SELATAN. Abdi Laksana: Jurnal Pengabdian Kepada Masyarakat, 2(2), 295301.

Pasaribu, V. L. D., Yuniati, H. L., Pranata, R., Sembayu, R., Purba, S. M., \& Nurbayani, T. T. A. (2021). MANAJEMEN KEUANGAN UNTUK MENGHADAPI DAN BERTAHAN DI ERA COVID 19. Jurnal Abdimas Tri Dharma Manajemen, 2(2), 12-18.

Pasaribu, V. L. D., Dwiyatni, A., Sabina, C., Ridwan, M., Gunawan, D. D., \& Noviani, B. C. (2021). EVALUASI PENERAPAN 3M DIMASA PANDEMIC COVID 19. Jurnal Abdimas Tri Dharma 
Loyalitas Kreativitas Aldi Masyarakat Kreatif
Manajemen, 2(2), 54-60.

Pasaribu, V. L. D., Syafei, A. N., Farhan, A., Aufaizah, A., Irani, C., \& Firtiayani, S. R. (2021). PENGARUH DISPLIN PROTOKOL KESEHATAN TERHADAP PENCEGAHAN PENULARAN VIRUS COVID19. Jurnal Abdimas Tri Dharma Manajemen, 2(2), 91-98.

Pasaribu, V. L. D., Septiani, F., Rahayu, S., Lismiatun, L., Arief, M., Juanda, A., ... \& Rahim, R. (2021). Forecast Analysis of Gross Regional Domestic Product based on the Linear Regression Algorithm Technique.

Priadi, A., Pasaribu, V. L. D., Virby, S., Sairin, S., \& Wardani, W. G. (2020). Penguatan Ekonomi Kreatif Berbasis Sumber Daya Desa Dikelurahan Rempoa. Abdi Laksana: Jurnal Pengabdian Kepada Masyarakat, 1(3), 356-35

Pasaribu, V. L. D., Priadi, A., Anismadiyah, V., Rahayu, S., \& Maduningtias, L. (2021). PENYULUHAN KREATIF DAN INOVATIF

MENINGKATKAN MUTU PRODUKSI UMKM DI DESA BELEGA KABUPATEN GIANYAR. Pro Bono Jurnal Pengabdian Kepada Masyarakat, 1(02).

Pasaribu, V. L. D. (2021). PELATIHAN BERBASIS ONLINE DI ERA COVID-19. Jurnal Abdimas Tri Dharma Manajemen, 2(3), 2632.
Pasaribu, V. L. D., \& Setyowati, R. (2021). ADAPTASI KEHIDUPAN NEW NORMAL PADA MASA PANDEMI COVID-19 DIYAYASAN PONDOK PESANTREN DAN PANTI ASUHAN NURUL IKHSAN KECAMATAN SETU, KOTA TANGERANG SELATAN. Jurnal Lokabmas Kreatif: Loyalitas Kreatifitas Abdi Masyarakat Kreatif, 2(2), 82-88.

http://

http://hukor.kemkes.go.id/uploads/produk hukum/KMK_No_HK_01_07-MENKES.pdf

Sari, D. P dan Atiqoh, N. S. (2020). Hubungan antara Pengetahuan Masyarakat dengan Kepatuhan Penggunaan Masker sebagai Upaya Pencegahan Penyakit Covid19 di Ngronggah. Jurnal Infokes 10 (1), 5255. Retrieved from https://ojs.udb.ac.id/index.php/infokes/articl e/view/850/755.

WHO. (2020). Anjuran Mengenai Penggunaan Masker dalam Konteks COVID-19. Retrieved September 22 from website: https://www.who.int/docs/defaultsource/searo/indonesia/covid19/anjuranmengenai-penggunaan-masker-dalamkonteks-covid-19.pdf?sfvrsn=8a209b04_2 
P-ISSN 2722-2101, E-ISSN 2722-4201

Loyalitas Kreativitas

Program Studi Ekonomi Manajemen Universitas Pamulang

Aldi Masyarakat Kreatif Jurnal LOKABMAS Kreatif Vol.02,No.03.Nov 2021 Hal.1-7

Email:jurnalkreatif.manajemen@gmail.com

\section{DOKUMENTASI KEGIATAN}
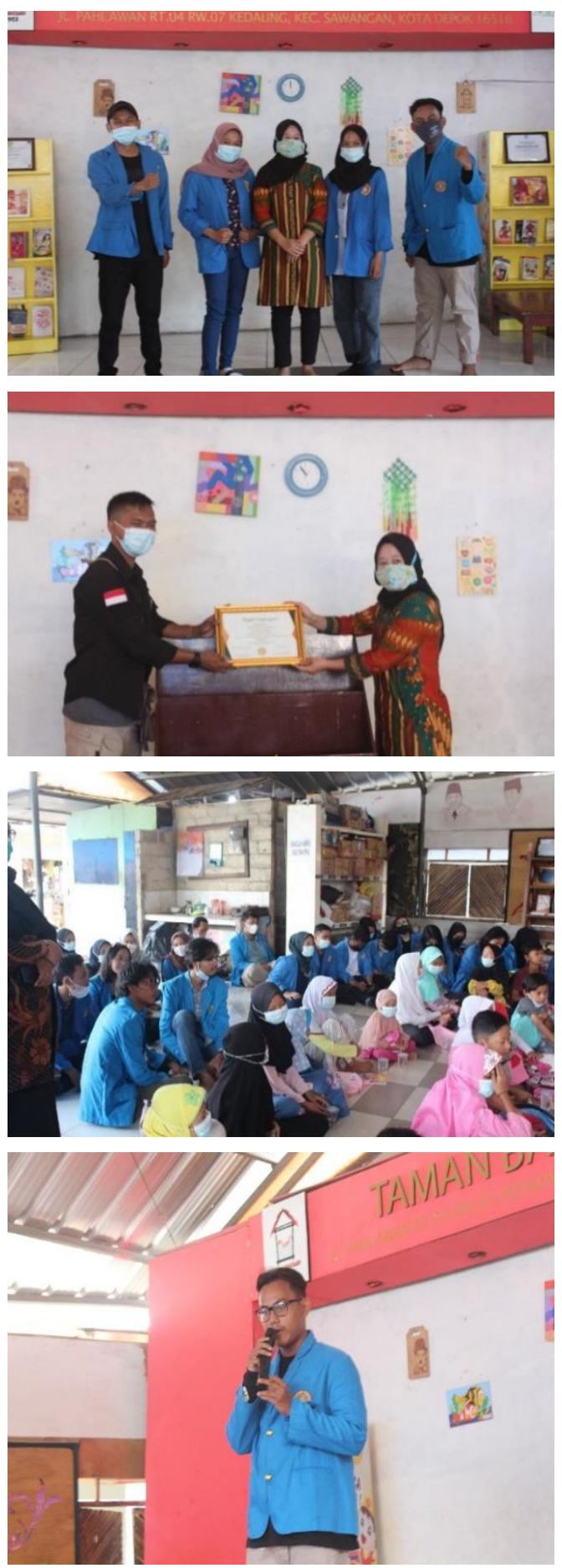